Gut, 1971, 12, 1001-1006

\title{
Glucose absorption kinetics in Zambian African patients with and without systemic bacterial infections
}

\author{
G. C. COOK \\ From the Department of Medicine, The University of Zambia
}

SUMMARY Using a double-lumen tube perfusion system, solutions of glucose $(1 \cdot 0,2 \cdot 5$, and $5 \cdot 0 \mathrm{~g}$ $100 \mathrm{ml}^{-1}$ ) have been perfused into the upper jejunum of 22 Zambian African subjects in order to study their glucose absorption kinetics. None of them had clinical evidence of malnutrition or intestinal disease. In 10 there was no evidence of an infective disease ('normal' group); seven had tuberculosis; five had acute bacterial infections. The mean serum albumin concentration was significantly lower in those with infections; the mean total and $\gamma$-globulin concentrations were significantly higher in the tuberculosis group.

There was good reproducibility in triplicate assessments of glucose and water absorption rates in the individual subjects. Despite a wide scatter, the mean glucose kinetic curves were significantly flatter in those with infections than in the normal group $(P<0.02)$. There was a significant association between glucose and water absorption rates in the individuals. D-xylose absorption was estimated in 11 subjects and there was a significant correlation between that and the glucose absorption rate. Jejunal morphology $(n=9)$ and disaccharidase concentrations $(n=6)$ were normal for African subjects and there were no significant associations between either of those and the absorption rates.

Galactose absorption kinetics have been studied in an additional four relatively normal Zambian Africans.

This study suggests that systemic bacterial infections can produce malabsorption. This may be relevant to the weight loss in patients with pulmonary tuberculosis and also to the aetiology of kwashiorkor.

The jejunal mucosa of the African subject living in Africa has a lower absorptive area than that of the European living in the United Kingdom; it consists predominantly of leaf- rather than finger-shaped villi (Coo, Kajubi, and Lee. 1969). This applies to Zambian Africans (G. C. Cook, unpublished observation). Some Ugandan African subjects have reduced D-xylose absorption (Cook et al, 1969); the reason for that is not clear, and it is not always associated with histological changes in the jejunum. Zambian patients with acute and chronic bacterial infections have recently been shown to have a significantly reduced absorption of D-xylose (Cook, 1971a).

The most sensitive available test of functional integrity of the jejunal mucosa is based on the

${ }^{1}$ Correspondence to Professor G. C. Cook, Department of Medicine, The University of Zambia, P.O. Box 2379, Lusaka, Zambia.

Received for publication 13 August 1971. perfusion of monosaccharide solutions of varying concentrations along a known segment of jejunum and the study of their absorption kinetics (Holdsworth and Dawson, 1965).

In the present investigation data have been obtained on glucose absorption kinetics in a group of Zambian African patients with and without systemic bacterial infections. Galactose absorption kinetics were also studied in a small group of relatively normal Zambian Africans.

\section{Subjects and Methods}

Twenty-two Zambian African patients were given glucose perfusions after the procedure had been explained to them. They were all inpatients at the University Teaching Hospital, Lusaka, and came from many different tribes (Brelsford, 1965). None had clinical evidence of malnutrition or intestinal disease. In 10 there was no evidence of an infection ('nor- 
mal' group). Infections were excluded on clinical grounds, and by chest radiographs, total and differential white cell counts, and examination of thick blood films. Seven had tuberculosis; in six this consisted of severe pulmonary disease with cavitation (confirmed by chest radiograph), and in one of tuberculous lymphadenopathy (confirmed by biopsy histology). Three of them had Mycobacterium tuberculosis in their sputum at the time of study; none was being treated for the disease. The mean duration of illness was 16 (1-60) months. Five had an acute bacterial infection; in four this consisted of pneumococcal lobar pneumonia (confirmed by chest radiograph), and in on $\epsilon$ of acute salpingitis. The mean duration of illness was two (0.5-4) weeks. Four were still pyrexial, and two were being treated with antibiotics. All of the infections had been recently diagnosed. There were three women in the normal group and one in each of the groups with infections. The mean ages of the subjects in the three groups were 37 (29-50), 39 (16-68), and 42 (26-55) years, and the mean body weights 57 (40-70), 49 (38-59), and 51 (46-60) kg respectively. Four other Zambian Africans without bacterial infections (one woman and three men) were given galactose perfusions. Their mean age was 28 (18-46) yr, and mean body weight 55 (54-59) kg.

The mean haemoglobin concentrations for the three groups were $12 \cdot 1(8 \cdot 8-14 \cdot 8), 10 \cdot 7(8 \cdot 8-13 \cdot 0)$, and $11 \cdot 1(8 \cdot 5-12 \cdot 5) \mathrm{g} 100 \mathrm{ml}^{-1}$ respectively. Table I summarizes the serum albumin, total globulin, and $\gamma$-globulin concentrations in 20 of the subjects who had glucose perfusions. Total protein was estimated in duplicate by a modification of the biuret method (Weischelbaum, 1946); electrophoresis was carried out using a Beckman R-101 microzome electrophoresis cell. All individual estimations were carried out on the same day. Two subjects in each of the normal $(n=7)$ and tuberculosis $(n=5)$ groups, and none in the acute infection $(n=3)$ group had hookworm ova in their stools. D-xylose absorption after a $25 \mathrm{~g}$ oral load (Christiansen, Kirsner, and Ablaza, 1959; Cook, 1971a) was estimated in 11 subjects. Each of them was very carefully supervised during the test period. The five-hour urinary excretion was measured by the method of Roe and Rice (1948). Jejunal biopsy specimens were obtained for histology and disaccharidase assays from nine subjects (Cook and Dahlqvist, 1968) (Table II). Part of the specimen was placed in $10 \%(w / v)$ formol-saline and the remainder was immediately frozen to $-20^{\circ} \mathrm{C}$ until estimation of the disaccharidases. All of the Dxylose tests were done and jejunal biopsy specimens were obtained within three days of the jejunal perfusions.

For the perfusion studies a double-lumen tube (Portex MLT/B, external diameter $4.2 \mathrm{~mm}$ ) with a proximal opening into one lumen at $30 \mathrm{~cm}$ from the end and three others into the other lumen at the end of the tube was used (Holdsworth and Dawson, 1964; Cook, 1971b). The tube was swallowed the evening before the study and sips of water were permitted throughout the night. After radiological checking of the position of the tube, perfusion was started between 16 and 18 hours after the tube had been swallowed. The mean position of the proximal opening in the three groups was 13 (1-39), 15 (3-28), and $22(7-38) \mathrm{cm}$ past the ligament of Treitz, respectively. Three solutions were perfused through the proximal opening with a constant infusion pump (Edmund Bühler, Tübingen) set at $12.0 \mathrm{ml} \mathrm{min}{ }^{-1}$, always in order of ascending concentration. Solution A contained $1.0 \mathrm{~g}^{100 \mathrm{ml}^{-1}}\left(56 \mathrm{~m}\right.$-mole $\left.1^{-1}\right)$

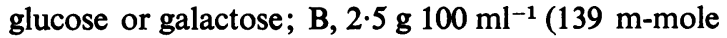
$\left.1^{-1}\right)$ glucose or galactose; and C, $5.0{\mathrm{~g} 100 \mathrm{ml}^{-1}}^{-1}$ $\left(278 \mathrm{~m}\right.$-mole $\left.1^{-1}\right)$ glucose or galactose. All of the solutions were rendered isotonic with the appropriate concentration of sodium chloride. They all contained

\begin{tabular}{|c|c|c|c|c|}
\hline Group & No. Subjects Studied & $\begin{array}{l}\text { Albumin }{ }^{2} \\
\left(\mathrm{~g} 100 \mathrm{ml}^{-1}\right)\end{array}$ & $\begin{array}{l}\text { Total Globulin } \\
\left(\mathrm{g} 100 \mathrm{ml}^{-1}\right)\end{array}$ & $\begin{array}{l}\gamma \text {-Globulin } \\
\left(\mathrm{g} 100 \mathrm{ml}^{-1}\right)\end{array}$ \\
\hline Normal & 10 & $\begin{array}{l}3 \cdot 2(2 \cdot 4-3.9) \\
+0 \cdot 16\end{array}$ & $\begin{array}{l}3.8(2 \cdot 8-6 \cdot 1) \\
+0 \cdot 31\end{array}$ & $\begin{array}{l}1.8(1.3-3.2) \\
+0.19\end{array}$ \\
\hline Tuberculosis & 6 & $\begin{array}{l}2 \cdot 3(1 \cdot 8-3 \cdot 1) \\
\pm 0 \cdot 18\end{array}$ & $\begin{array}{l}5 \cdot 1(4 \cdot 6-5 \cdot 6) \\
\pm 0 \cdot 16\end{array}$ & $\begin{array}{l}2 \cdot 6(2 \cdot 0-3 \cdot 3) \\
\pm 0 \cdot 18\end{array}$ \\
\hline Acute infection & 4 & $\begin{array}{l}2 \cdot 4(2 \cdot 3-2 \cdot 6) \\
\pm 0 \cdot 09\end{array}$ & $\begin{array}{l}4 \cdot 0(3 \cdot 6-4 \cdot 5) \\
\pm 0 \cdot 18\end{array}$ & $\begin{array}{l}1 \cdot 8(1 \cdot 4-2 \cdot 1) \\
\pm 0 \cdot 15\end{array}$ \\
\hline
\end{tabular}

Table I Serum albumin, total globulin, and $\gamma$-globulin concentrations in some of the subjects receiving glucose perfusions ${ }^{1}$

\footnotetext{
${ }^{1}$ The mean (and range) $\pm 1 \mathrm{SDM}$ are shown.

${ }^{2}$ The differences between means for the normal and tuberculosis $(t=3.35 ; P<0.01)$ and the normal and acute infection $(t=2.71 ; P<0.02)$ groups are significant. The means for the normal and tuberculosis + acute infection $(t=4 \cdot 06 ; P<0.001)$ groups are also significantly different. ${ }^{3}$ The differences between means for the normal and tuberculos is $(t=3 \cdot 13 ; P<0.01)$ and the tuberculosis and acute infection $(t=4 \cdot 18 ; P<0.01)$ groups are significant.

The difference between the means for the tuberculosis and acute infection $(t=3.16 ; P<0.02)$ groups are significant.
} 


\begin{tabular}{|c|c|c|c|c|c|c|c|c|c|c|c|}
\hline \multirow[t]{2}{*}{ Group } & \multirow{2}{*}{$\begin{array}{l}\text { Subject } \\
\text { No. }\end{array}$} & \multicolumn{5}{|l|}{ Histology } & \multicolumn{5}{|c|}{ Disaccharidases (units g protein ${ }^{-1}$ ) } \\
\hline & & $\begin{array}{l}\text { Appearance } \\
\text { (dissecting } \\
\text { microscope) }\end{array}$ & Epithelium ${ }^{1}$ & $\begin{array}{l}\text { Plasma } \\
\text { cells }\end{array}$ & $\begin{array}{l}\text { Neutro- } \\
\text { phils's }\end{array}$ & $\begin{array}{l}\text { Mucosal } \\
\text { Index }\end{array}$ & Lactase & Maltase & Isomaltase & Sucrase & Trehalase \\
\hline $\begin{array}{l}\text { Glucose perfusions } \\
\text { Normal } \\
\text { Normal } \\
\text { Tuberculosis } \\
\text { Tuberculosis } \\
\text { Tuberculosis } \\
\text { Tuberculosis }\end{array}$ & $\begin{array}{r}6 \\
9 \\
12 \\
13 \\
14 \\
16\end{array}$ & $\begin{array}{l}\text { Leaves } \\
\text { Leaves } \\
\text { Leaves } \\
\text { Leaves } \\
\text { Leaves } \\
\text { Leaves \& } \\
\text { fingers }\end{array}$ & $\begin{array}{l}1 \\
1 \\
1 \\
1 \\
- \\
1\end{array}$ & $\begin{array}{l}3 \\
2 \\
2 \\
2 \\
- \\
2\end{array}$ & $\begin{array}{l}1 \\
1 \\
1 \\
1 \\
- \\
1\end{array}$ & $\begin{array}{l}3 \cdot 0 \\
3 \cdot 9 \\
3 \cdot 0 \\
3 \cdot 0 \\
- \\
3 \cdot 0\end{array}$ & $\begin{array}{l}1 \cdot 5 \\
1 \cdot 3 \\
- \\
3 \cdot 5 \\
- \\
2 \cdot 0\end{array}$ & $\begin{array}{l}489 \\
120 \\
- \\
305 \\
- \\
435\end{array}$ & $\begin{array}{l}163 \\
37 \\
- \\
85 \\
- \\
138\end{array}$ & $\begin{array}{r}122 \\
60 \\
-\quad 69 \\
- \\
102\end{array}$ & $\begin{array}{l}52 \\
12 \\
- \\
29 \\
- \\
30\end{array}$ \\
\hline $\begin{array}{l}\text { Tuberculosis } \\
\text { Acute infection }\end{array}$ & $\begin{array}{l}17 \\
21\end{array}$ & $\begin{array}{l}\text { Leaves } \\
\text { Leaves }\end{array}$ & - & - & $\overline{-}$ & $\overline{-}$ & $\overline{2} \cdot 3$ & $\overline{193}$ & -52 & - & $\overline{14}$ \\
\hline $\begin{array}{l}\text { Galactose perfusions } \\
\text { Normal }\end{array}$ & 23 & $\begin{array}{l}\text { Leaves \& } \\
\text { ridges }\end{array}$ & 1 & 2 & 1 & $2 \cdot 9$ & $1 \cdot 4$ & 197 & 53 & 46 & 13 \\
\hline
\end{tabular}

Table II Results of the jejunal biopsy appearances, histology, and disaccharidase concentrations

$11=$ normal surface epithelium; ${ }^{2} 2=$ slight increase and $3=$ distinct increase in plasma cell infiltration;

3 = normal concentration of neutrophils, mainly in vessels.

"total mucosal height, divided by subvillous height.

\begin{tabular}{|c|c|c|c|c|}
\hline \multirow{2}{*}{$\begin{array}{l}\text { Monosaccharide or Water } \\
\text { Absorbed }\end{array}$} & \multirow[t]{2}{*}{ Absorption Rate } & \multicolumn{3}{|c|}{ Concentration of Monosaccharide in Perfusing Solution ( $\left.100 \mathrm{ml}^{-1}\right)$} \\
\hline & & $1 \cdot 0$ & $2 \cdot 5$ & $5 \cdot 0$ \\
\hline $\begin{array}{l}\text { Glucose } \\
\text { Galactose } \\
\text { Water from glucose solutions } \\
\text { Water from galactose solutions }\end{array}$ & 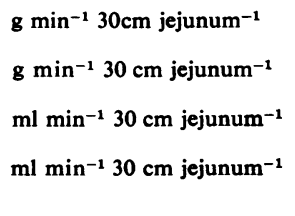 & $\begin{array}{l}0 \cdot 005 \\
(n=1) \\
0 \cdot 004 \\
(n=4) \\
1 \cdot 89 \\
(n=21) \\
0 \cdot 60 \\
(n=4)\end{array}$ & $\begin{array}{l}0.015 \\
(n=22) \\
0.017 \\
(n=4) \\
0.60 \\
(n=22) \\
0 \cdot 76 \\
(n=4)\end{array}$ & $\begin{array}{l}0.035 \\
(n=22) \\
0 \cdot 025 \\
(n=4) \\
0 \cdot 52 \\
(n=22) \\
0 \cdot 42 \\
(n=4)\end{array}$ \\
\hline
\end{tabular}

Table III Reproducibility of the monosaccharide and water absorption rates during the three separate 10-min collections ${ }^{1}$

${ }^{1}$ The standard deviation for the three estimates for each patient is given (Snedecor and Cochran, 1967):-

$$
\sigma=\sqrt{\frac{1}{\mathrm{n}(3-1)}\left(\Sigma \mathrm{Xti}^{2}-\frac{\left.\Sigma \mathrm{Xt}^{2}\right)}{3}\right)}
$$

where $\mathrm{n}=$ number of perfusions under consideration, $\Sigma \mathrm{Xti}^{2}=$ sum of the squares of all 10 -min collections under consideration, and $\Sigma \mathrm{X} \mathrm{t}^{2}=$ sum of the squares of the sums of the three 10 -min collections for each perfusion under consideration.

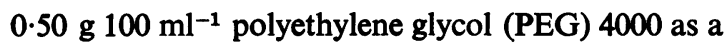
non-absorbable marker. After an equilibration period of $35 \mathrm{~min}$, three successive 10 -min samples were obtained from the distal opening of the tube by siphonage. Duplicate samples of siphonage were immediately deproteinized and estimated for their glucose concentration by a glucose-oxidase method (Marks, 1959); they were stored frozen until the estimations. Galactose was estimated by a galactoseoxidase (Boehringer pack) method. Polyethylene glycol estimations were carried out in duplicate on samples of the intestinal fluid which were also frozen immediately after collection (Hydén, 1956). Samples of all of the perfusion solutions were treated in an identical way to the siphoned samples of intestinal fluid and all were estimated at the same time as the test samples. The rates of glucose and water absorption were calculated by standard formulae (Sladen and Dawson, 1968). Table III summarizes the reproducibility of the monosaccharide and water absorption rates during the three 10-min collection periods of each perfusion. For the monosaccharides the coefficients of variation were all less than $15 \%$.

\section{Results}

\section{GLUCOSE ABSORPTION}

Figure 1 summarizes the mean glucose absorption

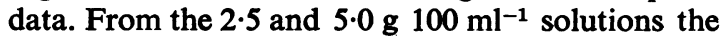
absorption rates were significantly depressed in the groups with infections. During the $2.5 \mathrm{~g}^{100 \mathrm{ml}^{-1}}$ perfusions the mean for the infection groups is 


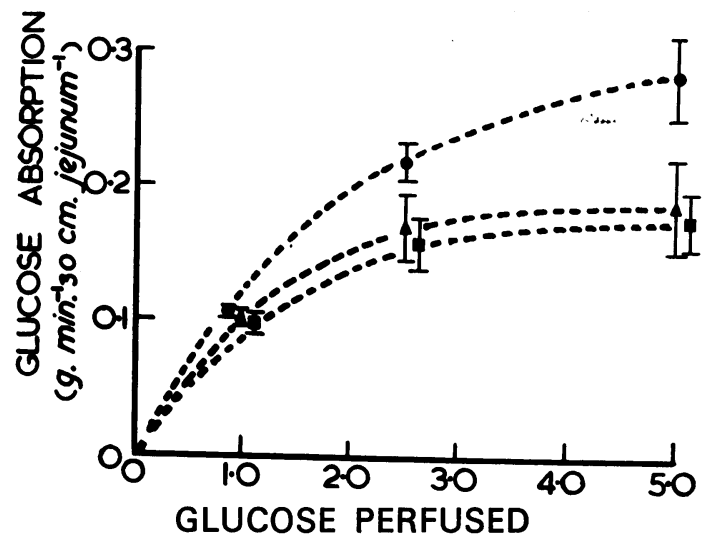

(g. $\left.100 \mathrm{ml}^{-1}\right)$

Fig. 1 Glucose absorption rates during the $1 \cdot 0,2 \cdot 5$, and

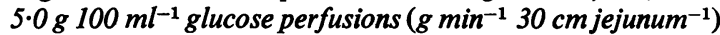
, 'normal' group; $\Delta$, tuberculosis group; $\square$, acute infection group. The mean \pm 1 SDM are shown for each point. The difference between the means for the normal and tuberculosis + acute infection groups during the $5.0 \mathrm{~g} 100 \mathrm{ml}^{-1}$ perfusions is significant $(t=2 \cdot 71$; $n=22 ; \mathrm{P}<0.02)$.

significantly lower than for the normal group $(\mathrm{t}=2.49 ; \mathrm{n}=22 ; \mathrm{P}<0.05)$; that for the acute infection group is also significantly lower than that for the normal group $(t=2.54 ; n=15 ; P<0.05)$.

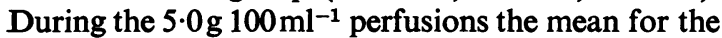
infection groups is significantly lower than for the normal group $(t=2.71 ; n=22 ; P<0.02)$; that for the acute infection group is also significantly lower than that for the normal group $(t=2 \cdot 26 ; n=15$;

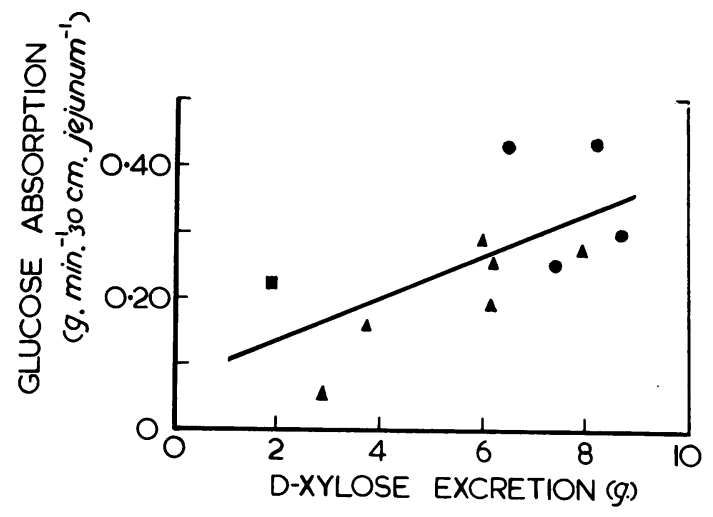

Fig. 2 Correlation between urinary d-xylose excretion and glucose absorption rates during the $5.0{\mathrm{~g} 100 \mathrm{ml}^{-1}}^{-1}$ glucose perfusions in 11 of the patients studied. , 'normal' group; $\Delta$, tuberculosis group; $\square$, acute infection group. The correlation is significant $(r=+$ $0.647 ; n=11 ; \mathrm{P}<0.05)$. The calculated regression line is shown: $y=0.072+0.032(x)$.
$P<0.05)$. In five subjects, one in the normal group and two in each of the tuberculosis and acute infection groups, the absorption rate during the $5.0{\mathrm{~g} 100 \mathrm{ml}^{-1}}^{-1}$ perfusion was less than $0 \cdot 15 \mathrm{~g} \mathrm{~min}^{-1} 30 \mathrm{~cm}_{\text {jejunum }}^{-1}$. The correlation between absorption rates from the

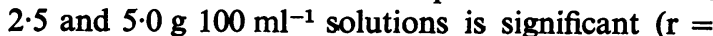
$+0.913 ; \mathrm{n}=22 ; \mathrm{P}<0.001$ ). Correlations between the individual absorption rates and age, body weight, haemoglobin, serum albumin and total globulin concentrations, and distance of the proximal opening of the tube past the ligament of Treitz, are not significant.

Figure 2 summarizes the results for D-xylose absorption in 11 subjects. The correlation between five-hr D-xylose excretion and glucose absorption rate from the $2.5(P<0.05)$ and $5.0(P<0.05) \mathrm{g}^{100 \mathrm{ml}^{-1}}$ solutions in the individuals is significant. Three subjects (two with tuberculosis and one an acute infection) had a five-hr excretion of less than $4.0 \mathrm{~g}$.

WATER ABSORPTION

Figure 3 summarizes the mean net water absorption

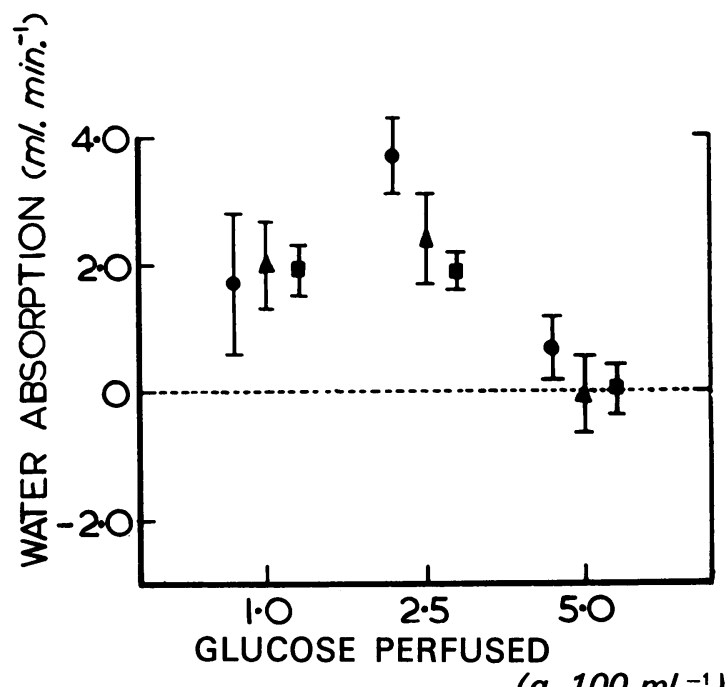

Fig. 3 Net water absorption rates during perfusion of

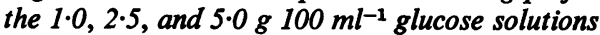
( $\left.\mathrm{ml} \mathrm{min}^{-1} 30 \mathrm{~cm}_{\text {jejunum }}{ }^{-1}\right)$. , 'normal' group; $\Delta$, tuberculosis group; $\square$, acute infection group. The mean \pm 1 SDM are shown for each point.

rates during the glucose perfusions. From the 2.5 and

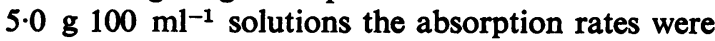
depressed in the groups with infections. The mean

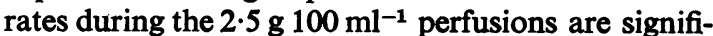
cantly higher than during the $5.0 \mathrm{~g} 100 \mathrm{ml}^{-1}$ per- 


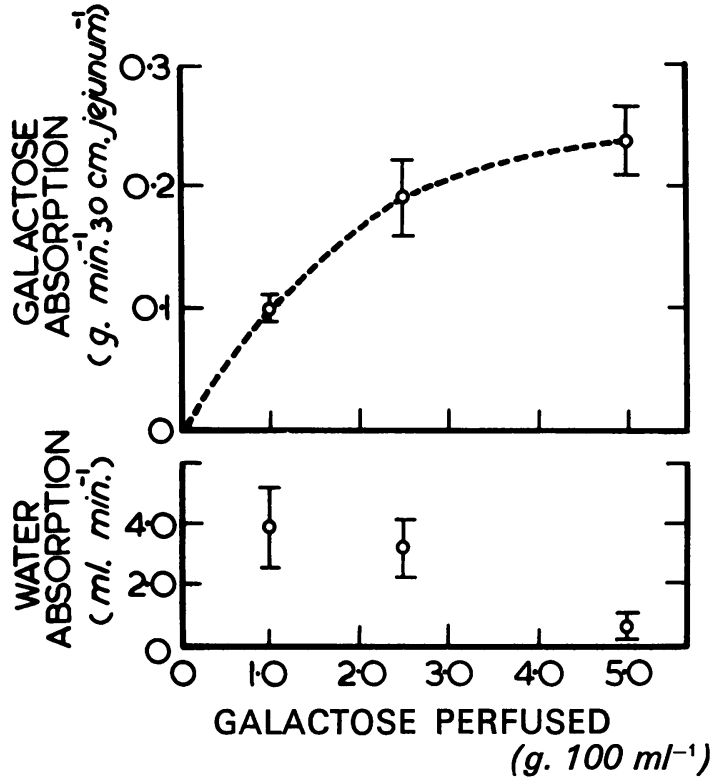

Fig. 4 Galactose and net water absorption rates during

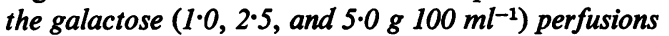
$\left(\mathrm{g} \mathrm{\textrm {min } ^ { - 1 } 3 0 \mathrm { cm } \text { jejunum }}{ }^{-1}\right)$. The mean \pm 1 SDM are shown for each point.

fusions in the normal $(\mathrm{t}=3.30 ; \mathrm{n}=20 ; \mathrm{P}<0.01)$, tuberculosis $(t=2.38 ; n=14 ; \mathrm{P}<0.05)$, and acute infection $(t=3.50 ; n=10 ; P<0.01)$ groups. The correlation between absorption rates from the 2.5

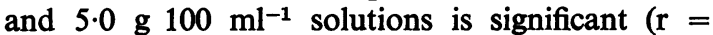
$+0.697 ; n=22 ; \mathrm{P}<0.001)$. The correlation between individual absorption rates and serum albumin concentrations are not significant during any of the perfusions.

GLUCOSE AND WATER ABSORPTION

During the $2.5(\mathrm{r}=+0.707 ; \mathrm{n}=22 ; \mathrm{P}<0.001)$ and $5.0(\mathrm{r}=+0.627 ; \mathrm{n}=22 ; \mathrm{P}<0.01) \mathrm{g} 100 \mathrm{ml}^{-1}$ perfusions the correlations between individual glucose and water absorption rates are significant.

\section{GALACTOSE ABSORPTION}

Figure 4 summarizes the results for galactose and water absorption. The mean galactose kinetic curve was slightly lower than that for glucose in the normal group but owing to the small number of subjects the difference is not significant.

\section{Discussion}

Results obtained with the double-lumen tube perfusion system without luminal occlusion, as used in the present study, are subject to inaccuracies due to reflux of perfusion fluid and contamination by upper intestinal secretions (Fordtran, 1969; Modigliani and Bernier, 1971). However, these factors do not influence the conclusion of the present investigation in which absorption rates from solutions of the same concentration have been compared in a number of different subjects. The reproducibility of the results obtained from three successive 10-min samples was good for monosaccharide and to a lesser extent water absorption rates (Holdsworth and Dawson, 1964; Sladen and Dawson, 1968 and 1970).

Despite a wide range in different individuals, the study clearly shows that the glucose kinetic curve is significantly flattened in subjects with systemic bacterial infections. This observation is in line with a previous demonstration that $\mathrm{D}$-xylose absorption is impaired in the presence of similar infections (Cook, 1971a). The relatively normal subjects in the present investigation also had flatter glucose and galactose absorption curves than English subjects studied in London by Holdsworth and Dawson (1964) (Figs. 1 and 4). However, it is impossible to make a direct comparison with that study because the perfusion rate used was $20 \mathrm{ml} \mathrm{min}^{-1}$. Nevertheless, at a high glucose concentration in the perfusing fluid the calculated absorption rate seems to be influenced to a lesser extent than at a low concentration (Modigliani and Bernier, 1971). The fact that some Zambian African subjects without bacterial infections have a relative impairment of D-xylose absorption (Cook, 1971a) suggests that the African jejunal mucosa (Cook et $a l, 1969)$ is frequently associated with some degree of malabsorption.

The practical importance of the present observation is not clear. However, in four of the subjects with infections and in one normal subject the glucose curves were very flat and comparable to those in patients with adult coeliac disease reported by Holdsworth and Dawson (1965). This suggests that a proportion of Zambians have a significant malabsorption of carbohydrate which forms the bulk of their diet (Richards, 1962). There was a significant positive correlation between D-xylose and glucose absorption rates in the 11 subjects tested (Fig. 2). The groups with infections also had lower mean net water absorption rates (Fig. 3). Such a reduction has previously been demonstrated in patients with adult coeliac disease, most of whom had a flat jejunal mucosa (Holdsworth and Dawson, 1965). There was a significant correlation between glucose and water absorption rates. The cause of the absorptive defect is not clear; it does not seem to be associated with a morphological change in the jejunal mucosa (Table II). It would be of interest, however, to carry out electron microscope studies of the jejunal mucosa in 
similar groups of subjects. Whether malaria and other systemic parasitic diseases can also influence glucose and xylose absorption rates has not been investigated.

The results could explain part of the weight loss in patients with acute and especially chronic infections. Bacterial infections are often associated with severe malnutrition (Wharton, 1970); it is possible that malabsorption resulting from such infections is important in the aetiology of kwashiorkor. The groups with infections had a significant reduction in the mean serum albumin concentration. Although that was probably a result of the infection, it could have been associated with marginal malnutrition which predisposed to the infection. However, all of the subjects were clinically well nourished. The present study may in part explain the relatively flat glucose-tolerance curve with a slow rise often seen in African subjects (Tulloch and Patel, 1969). In a study in South Africa, although blood glucose concentrations following oral glucose were similar in African and well matched white subjects, the rise in blood insulin was significantly less in the Africans $(P<0.02)$ (Rubenstein, Seftel, Miller, Bersohn, and Wright, 1969); the fasting blood glucose and insulin concentrations were similar in the two groups. Some of the clinical features of the coeliac syndrome, eg, a distended abdomen, low blood pressure, and finger clubbing are relatively common in Zambian African subjects; it seems possible that they are associated with some degree of malabsorption. In a follow-up study of patients with adult coeliac disease in Birmingham, England, a high incidence of carcinoma of the oesophagus has been found (Harris, Cooke, Thompson, and Waterhouse, 1966). Oesophageal carcinoma is prevalent in some parts of Zambia (McGlashan, 1969) and East Africa (Cook and Burkitt, 1971); there may be a link with malabsorption.

I thank Mr James Tembo for his careful supervision of the patients and for acting as my interpreter. $\mathrm{Mr}$ R. W. Wenlock was responsible for the serum protein electrophoresis estimations. I am grateful to Dr Arne Dahlquist and Dr N. O. Berg for enzyme estimations and histological interpretations of the jejunal biopsy specimens which will be published in detail elsewhere, and to Dr A. M. Dawson and Dr G. E. Sladen for discussion on the techniques of jejunal perfusion. I acknowledge with thanks financial support from the University of Zambia research fund.

\section{References}

Brelsford, W. V. (1965). In The Tribes of Zambia. Government Printer, Lusaka.

Christiansen, P. A., Kirsner, J. B., and Ablaza, J. (1959). D-xylose and its use in the diagnosis of malabsorptive states. Amer. J. Med., 27, 443-453.

Cook, G. C. (1971 a). Impairment of d-xylose absorption in Zambian African patients with systemic bacterial infections. (Submitted for publication.)

Cook, G. C. (1971b). Impairment of glycine absorption by glucose and galactose in man. J. Physiol. (Lond)., 217, 61-70.

Cook, G. C., and Dahlqvist, A. (1968). Jejunal getero- $\beta$-galactosidase activities in Ugandans with lactase deficiency. Gastroenterology, $55,328-332$.

Cook, G. C., Kajubi, S. K., and Lee, F. D. (1969). Jejunal morphology of the African in Uganda. J. Path., 98, 157-169.

Cook, P. J., and Burkitt, D. P. (1971). Cancer in Africa. Brit. med. Bull, , 27, 14-20.

Fordtran, J. S. (1969). Segmental perfusion techniques. Gastroenterology, 56, 987-989.

Harris, O. D., Cooke, W. T., Thompson, H., and Waterhouse, J. A. H. (1966). Malignancy in adult coeliac disease and idiopathic steatorrhoea. Gut, 7, 710-711.

Holdsworth, C. D., and Dawson, A. M. (1964). The absorption of monosaccharides in man. Clin. Sci., 27, 371-379.

Holdsworth, C. D., and Da wson, A. M. (1965). Glucose and fructose absorption in idiopathic steatorrhoea. Gut, 6, 387-391.

Hydén, S. (1956). A turbidometric method for the determination of higher polyethylene glycols in biological materials. $K$. LandbrHögsk. Annir., 22, 139-145.

Marks, V. (1959). An improved glucose-oxidase method for determining blood, CSF and urine glucose levels. Clin. chim. Acta, 4, 395-400.

McGlashan, N. D. (1969). Oesophageal cancer and alcoholic spirits in central Africa. Gut, 10, 643-650.

Modigliani, R., and Bernier, J. J. (1971). Absorption of glucose, sodium, and water by the human jejunum studied by intestinal perfusion with a proximal occluding balloon and at variable flow rates. Gut, 12, 184-193.

Richards, A. I. (1969). In Land, Labour and Diet in Northern Rhodesia, p. 425. Oxford University Press, London.

Roe, J. H., and Rice, E. W. (1948). A photometric method for determination of free pentoses in animal tissues. J. biol. Chem., 173, 507-512.

Rubenstein, A. H., Seftel, H. C., Miller, K., Bersohn, I., and Wright, A. D. (1969). Metabolic response to oral glucose in healthy South African white, Indian and African subjects. Brit. med. J., 1, 748-751.

Sladen, G. E., and Dawson, A. M. (1968). An evaluation of perfusion techniques in the study of water and electrolyte absorption in man: the problems of endogenous secretions. Gut, 9, 530-535.

Sladen, G. E., and Dawson, A. M. (1970). Further studies on the perfusion method for measuring intestinal absorption in man; the effects of a proximal occlusive balloon and a mixing segment. Gut, 11, 947-954.

Snedecor, G. W., and Cochran, W. G. (1967). In Statistical Methods, 6th ed., pp 258-298. Iowa State University Press, Ames, Iowa.

Tulloch, J. A., and Patel, K. M. (1969). Studies of normal carbohydrate tolerance in the Ugandan African. Trans. roy. Soc. trop. Med. Hyg., 63, 644-649.

Weischelbaum, T. E. (1946). An accurate and rapid method for the determination of proteins in small amounts of blood serum and plasma. Amer. J. clin. Path., 16 (Tech. Sect. 10), 40-49.

Wharton B. A. (1970). Child health and nutrition. In Modern Trends in Paediatrics, edited by J. Apley, pp 171-215. Butterworth, London. 